\title{
Flexão estática de madeira de Eucalyptus grandis: espaçamento e efeito da variação radial
}

\section{Static bending of Eucalyptus grandis wood: plant spacing and radial variation effect}

Luana Candaten ${ }^{1}$, Henrique Weber Dalla Costa ${ }^{3}$, Rômulo Trevisan ${ }^{2}$, Elder Eloy ${ }^{2}$, Darci Albertto Gatto ${ }^{4}$

\footnotetext{
${ }^{1}$ Universidade de São Paulo, Escola Superior de Agricultura "Luiz de Queiroz", Departamento de Ciências Florestais, Av. Pádua Dias, 235, Agronomia, CEP: 13418-900, Piracicaba, SP, Brasil.

${ }^{2}$ Universidade Federal de Santa Maria, Campus Frederico Westphalen, Departamento de Engenharia Florestal, Linha 7 de Setembro, s/n., CEP: 98400-000, BR 386, Km 40, Frederico Westphalen, RS, Brasil.

${ }^{3}$ Universidade Federal de Santa Maria, Centro de Ciências Rurais, Av. Roraima, 1000, CEP: 97105-900, Cidade Universitária, Camobi, Santa Maria, RS, Brasil..

${ }^{4}$ Universidade Federal de Pelotas, Campus Universitário, s/n, CEP: 96160-000, Capão do Leão, Pelotas, RS, Brasil e-mail: 1candaten@usp.br, romulo_trevisan@ufsm.br, elderufsm@gmail.com, hwdallacosta@gmail.com, darcigatto@yahoo.com
}

\section{RESUMO}

Estudos que abordam os parâmetros tecnológicos da madeira de amplo uso, como Eucalyptus grandis, são fundamentais, uma vez que seu uso e exploração adequados dependem dessas características. Atualmente, o implante dessa espécie foi ampliado e o espaçamento é um fator determinante. Portanto, o objetivo do presente estudo foi avaliar o espaçamento das plantas e a variação radial na flexão estática da madeira de Eucalyptus grandis. Para a condução do experimento, foram amostradas seis árvores para cada espaçamento: 2,0 x 1,0 m, 3,0 x 1,0 e $0 \times 1,5 \mathrm{~m}$, totalizando 18 indivíduos aos sete anos de idade. Posteriormente, o primeiro registro de cada amostra foi seccionado em placas radiais e depois transformado em corpos de prova, identificados em intervalos regulares na direção da casca da medula, com dimensões de 2,5 x 2,5 x 41,0 cm, para realizar o teste de flexão estática mecânica, seguindo as recomendações da ASTM D-143. Os resultados da resistência mecânica mostraram uma variação na direção da casca da medula, onde os maiores valores de Módulo de Elasticidade (MOE), Módulo de Ruptura (MOR) e Tensão do Limite Proporcional (TPL) estavam próximos da casca. No entanto, o espaçamento não alterou o MOE, MOR e TLP do material submetido à flexão estática. Assim, apenas a posição radial influencia na qualidade da madeira. Os valores das propriedades mecânicas estudadas tiveram um aumento no sentido medula-casca, sendo mais acentuados na região próxima a casca.

Palavras-chave: Propriedades tecnológicas; Propriedades mecânicas; Densidade populacional; Espécies de crescimento rápido.

\begin{abstract}
Studies that approach the technological parameters of wood with wide use, such as Eucalyptus grandis, are fundamental, since their suitable use and exploitation are dependent on these characteristics. Currently, this species implantation has been expanded and the spacing is a determining factor. Therefore, the aim of present study was to evaluate the plant spacing and radial variation in static bending of Eucalyptus grandis wood. For the experiment conduction, six trees were sampled for each spacing: $2.0 \times 1.0 \mathrm{~m}, 3.0 \times 1.0 \mathrm{~m}$ and $3.0 \times 1.5 \mathrm{~m}$, totalizing 18 specimen at seven years old. Subsequently, the first log of each sample was sectioned into radial boards and then made into test specimens, which were identified at regular intervals in the pith-bark direction, with dimensions of $2.5 \times 2.5 \times 41.0 \mathrm{~cm}$, to perform the mechanical static bending test, following the ASTM
\end{abstract}


recommendations. The mechanical resistance results showed a variation in the pith-bark direction, where the highest MOE, MOR and TPL values were near to the bark. However, the spacing did not change the modulus of elasticity, modulus of rupture and tension on proportional limit of the material subjected to static bending. Thus, only the radial position influences in the wood quality. The values of the studied mechanical properties had an increase in the pith-bark direction, being more accentuated in the region near the bark.

Keywords: Technological properties; Mechanical properties; Population density; Fast-growing species.

\section{INTRODUCTION}

The high demand for raw materials combined with the restriction of environmental laws made it necessary to introduce exotic and fast-growing species GALLIO et al. [1] in commercial timber production. Among the introduced species, those of the Eucalyptus genus are highlighted, with increasing rates in the different activities of the forest sector [2] due to its fast-growing, high energy density, low-temperature tolerance and, according to LOPES et al. [3], the Eucalyptus grandis W. Hill ex Maiden species stands out for its high importance in commercial, industrial and residential sectors.

In the commercial wood production, the spacing is among the most relevant indicatives, being highlighted in scientific studies, that address the correct use through planting rows experiments in the most diverse environments and indicating in which situations it should be expanded or reduced [4- 6]. The spacing in short rotation planting, such as the rose gum case, directly influences the technological properties of the produced wood, due to characteristics such as the rate and form of growth and formation of juvenile and mature wood $[7,2]$. Therefore, researches that characterize the wood quality should be adopted to highlight the relation of the technological properties with the spacing applied LOPES et al. [3] besides being fundamental in indicating the best final product use.

The initial planting spacing aggregates in their density that from silvicultural techniques can result in altered growth and formation of woody material [8]. According to LIMA et al. [8] the initial spacing with smaller growing areas have no influence on the wood technological properties from hardwood species. Regarding the high growing space between plants, [10] observed differences in the Eucalyptus grandis and Eucalyptus saligna woods specific gravity, a physical property of wood directly linked to its mechanical characteristics [11]. In addition, [12] found an increase in the physical and mechanical properties of Eucalyptus saligna wood from the widening of the planting spacing.

In addition to the site conditions influencing the wood technological properties, variations occur in the same specimen, which are more well-defined in the radial direction than in the axial direction, thus, the characterization of the material in its different anatomical profiles is of utmost importance [13].

From this note, the knowledge of the technological characteristics evaluated internally are important for the improvement of the material quality and employability, obtaining more homogeneous wood batches and thus, adding value to wood products, and the lack of knowledge of these parameters makes their use unviable [14]. Therefore, studies are needed to investigate the mechanical properties of wood when inserted in different conditions, such as different sites, growing spaces between plants, anatomical positions in the stem. The wood strength can be evaluated by mechanical stress in the static bending assays allowing comparisons with species already studied and characterized in the literature [15]

The static bending assay enables to know the mechanical properties of a material, determining its strength when submitted to a stress. Up to the proportional limit, reversible deformations occur, after that, they become plastic or irreversible deformations. The static bending study provides knowledge of modulus of elasticity (MOE) and modulus of rupture (MOR), which contribute in the mechanical strength classification, based on the moisture content and specific gravity of the samples.

The study of radial variation in wood from commercial timber production at different plant spacing is essential to determine the most appropriate spacing and the log region in which the wood presents the best mechanical strength characteristics. Thus, the aim of the present study was to evaluate the influence of plant spacing and radial variation on the mechanical properties of Eucalyptus grandis wood, through the static bending assay.

\section{MATERIAL AND METHODS}

The material originated from a 7-year-old Eucalyptus grandis forest, implanted with the following planting spacing: $2.0 \times 1.0 \mathrm{~m} ; 3.0 \times 1.0 \mathrm{~m}$ and $3.0 \times 1.5 \mathrm{~m}$, at the geographical coordinates $27^{\circ} 22^{\prime \prime} \mathrm{S} ; 53^{\circ} 25^{\prime \prime} \mathrm{W}$, at 
$480 \mathrm{~m}$ altitude. To carry out the experiment, after harvesting, the first log of each of the six trees sampled by spacing was selected, totaling 18 samples.

Then, the logs were sawn in radial planks and from the planks were made, on average, 10 specimens with $2.5 \times 2.5 \times 41.0 \mathrm{~cm}^{3}$ (width $\mathrm{x}$ thickness $\mathrm{x}$ length) of each $\log$, according to the ASTM D-143-94 standard [22], to perform the static bending assay (Figure 1). The specimens were properly identified in the pith-bark relative position and air-dried until the hygroscopic stabilization. The static bending assay was performed in an EMIC ${ }^{\circledR}$ universal testing machine, equipped with data acquisition system. The values of modulus of elasticity (MOE), modulus of rupture (MOR) and tension on the proportional limit (TPL), were obtained.

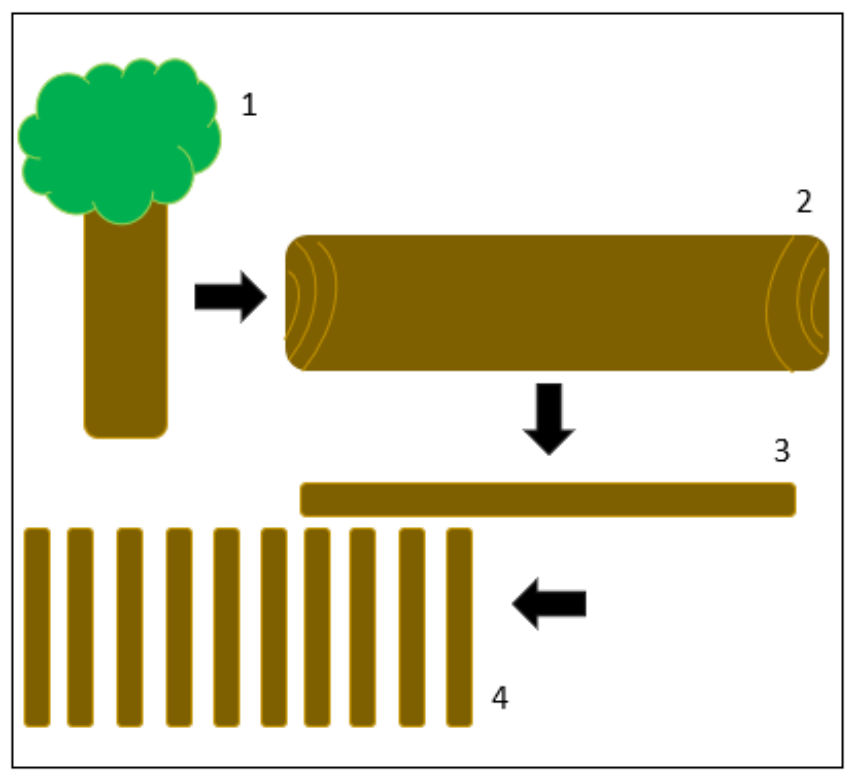

Figure 1: Schematic representation of the fabrication of the specimens. 1 - Tree used. 2 - Log where the center board was used. 3 - Central board session of the first trunk (approximately base up to 3 meters) used in the manufacture of the test specimens for mechanical pith-bark testing. 4 - Specimens for MOE, MOR e TLP.

For the determination of each plant spacing in the radial variation of rose gum wood mechanical properties, the data sampled by relative position were submitted to regression analysis, in the statistical package "Statistical Analysis System" SAS (2000), using the Stepwise procedure of equation modelling (Equation 1).

$$
\text { MOE;MOR;TPL }=\mathrm{f}\left(\mathrm{P} ; \frac{1}{\mathrm{P}} ; \mathrm{P}^{2} ; \frac{1}{\mathrm{P}^{2}} ; \ln \mathrm{P} ; \frac{1}{\ln \mathrm{P}} ; \sqrt{\mathrm{P}} ; \frac{1}{\sqrt{\mathrm{P}}}\right)
$$

Where: MOE, MOR, TPL = modulus of elasticity, modulus of rupture and tension on proportional limit, respectively, $\mathrm{Kgf} / \mathrm{cm}^{2} ; \mathrm{P}=$ relative position (pith-bark direction), $\%$.

The model was selected after the analysis of the distribution of residuals, standard error of the estimate (Sxy), adjusted coefficient of determination $\left(\mathrm{R}^{2} \mathrm{ad}\right)$ and calculated $\mathrm{F}$ value. Then, in the equation to describe the radial variation of the MOE, MOR and TPL, Dummy variables were added, which assumed values of 0 and 1 , according to the applied plant spacing, as follows: $\mathrm{Di}=1$, if the tree was present at "i" spacing; $\mathrm{Di}=0$, if the tree was absent at " $\mathrm{i}$ " spacing. Thus, it was possible to determine individual adjusted regressions for plant spacing as a function of a multiple linear regression, represented by the independent variables described in Equation 2.

$$
\text { MOE;MOR;TPL=f (X;Di;Di.X) }
$$

Where: MOE, MOR, TPL = modulus of elasticity, modulus of rupture and tension on proportional limit, respectively, $\mathrm{Kgf} / \mathrm{cm}^{2} ; \mathrm{X}=$ relative position (pith-bark direction) determined by Stepwise, \%; Di = Dummy (plant spacing, "i" = $2.0 \times 1.0 \mathrm{~m} ; 3.0 \times 1.0 \mathrm{~m}$ ); Di.X = interaction of the Di variable with the X variable. 


\section{RESULTS}

The coefficients and the equations statistics to describe the modulus of elasticity, modulus of rupture and the tension on the proportional limit of the Eucalyptus grandis trees as a function of the relative position in the pith-bark direction, are in Table 1. The addition of more independent variables to the models was not possible for a $5 \%$ level of error probability.

Table 1: Equations obtained from Stepwise procedure to describe the modulus of elasticity, modulus of rupture and tension on proportional limit of 7-years-old Eucalyptus grandis, in function of the relative position in pith-bark direction.

\begin{tabular}{|c|c|c|c|c|c|c|c|}
\hline \multirow{2}{*}{ Step } & \multirow{2}{*}{ Model } & \multicolumn{4}{|c|}{ Statistics } & \multirow{2}{*}{$\mathrm{R}_{\text {ad. }}^{2}$} & \multirow{2}{*}{$\mathrm{F}$} \\
\hline & & $b_{j}$ & Value & $F^{\prime}$ & $\operatorname{Pr}>F$ & & \\
\hline \multirow{2}{*}{1} & \multirow{2}{*}{$\mathrm{MOE}=\mathrm{b}_{0}+\mathrm{b}_{1}(\mathrm{LnP})$} & $\mathrm{b}_{0}$ & 20978 & 14.2 & $<0.001 * *$ & \multirow{2}{*}{0.42} & \multirow{2}{*}{129.9} \\
\hline & & $\mathrm{b}_{1}$ & 17344 & 129.9 & $<0.001 * *$ & & \\
\hline \multirow{2}{*}{1} & \multirow{2}{*}{$\mathrm{MOR}=\mathrm{b}_{0}+\mathrm{b}_{1}(1 / \mathrm{LnP})$} & $\mathrm{b}_{0}$ & 972.8 & 448.2 & $<0.001 * *$ & \multirow{2}{*}{0.17} & \multirow{2}{*}{37.4} \\
\hline & & $\mathrm{b}_{1}$ & -956.6 & 37.4 & $<0.001 * *$ & & \\
\hline \multirow{2}{*}{1} & \multirow{2}{*}{$\mathrm{TPL}=\mathrm{b}_{0}+\mathrm{b}_{1}(1 / \mathrm{LnP})$} & $\mathrm{b}_{0}$ & 717.4 & 565.2 & $<0.001 * *$ & \multirow{2}{*}{0.33} & \multirow{2}{*}{85.5} \\
\hline & & $\mathrm{b}_{1}$ & -949.4 & 85.5 & $<0.001 * *$ & & \\
\hline
\end{tabular}

Where: $\mathrm{MOE}=$ modulus of elasticity, $\mathrm{kgf} / \mathrm{cm}^{2} ; \mathrm{MOR}=$ modulus of rupture, $\mathrm{kgf} / \mathrm{cm}^{2} ; \mathrm{TPL}=$ tension on proportional limit, $\mathrm{kgf} / \mathrm{cm}^{2} ; \mathrm{P}=$ relative position (pith-bark direction), \%; $\mathrm{b} \mathrm{r}_{\mathrm{i}}=$ equation coefficient; $\mathrm{F}$ ' = calculated $\mathrm{F}$ value for coefficients hypothesis test; $\mathrm{Pr}>\mathrm{F}=$ level of error probability; $\mathrm{R}_{\text {ad. }}^{2}$ = adjusted coefficient of determination; $\mathrm{F}=$ calculated $\mathrm{F}$ value for the model; $* *=$ significant at the $1 \%$ level of error probability.

The selected equations for the modulus of elasticity, modulus of rupture and tension on the proportional limit as a function of the relative position in the pith-bark direction were related to the respective plant spacing and submitted to regression analysis with the use of the Dummy variable (Table 2).

Table 2: Regression analysis with Dummy variable (type SS1) of modulus of elasticity, modulus of rupture and tension on proportional limit of 7-years-old Eucalyptus grandis, in function of the relative position and plant spacing.

\begin{tabular}{|c|c|c|c|c|c|}
\hline \multicolumn{2}{|c|}{ MOE } & \multicolumn{2}{|c|}{ MOR } & \multicolumn{2}{|c|}{ TPL } \\
\hline $\mathrm{VS}$ & MS & $\mathrm{VS}$ & MS & $\mathrm{VS}$ & MS \\
\hline Model & $4806177084 * *$ & Model & $114921 * *$ & Model & $111203 * *$ \\
\hline $\mathrm{LnP}$ & $23748814125^{* *}$ & 1/LnP & $552997 * *$ & $1 / \mathrm{LnP}$ & $541190 * *$ \\
\hline D1 & $56463316^{\mathrm{ns}}$ & D1 & $1989.8^{\mathrm{ns}}$ & D1 & $245.2^{\mathrm{ns}}$ \\
\hline D2 & $58213201^{\mathrm{ns}}$ & D2 & $5833.6^{\mathrm{ns}}$ & D2 & $5.9^{\mathrm{ns}}$ \\
\hline D3 & . & D3 & . & D3 & . \\
\hline D1. LnP & $80597724^{\mathrm{ns}}$ & D1. 1/LnP & $3604.5^{\mathrm{ns}}$ & D1. 1/LnP & $3689.4^{\mathrm{ns}}$ \\
\hline D2. LnP & $86797057^{\mathrm{ns}}$ & D2. 1/LnP & $10182.2^{\mathrm{ns}}$ & D2. 1/LnP & $10884.1^{\mathrm{ns}}$ \\
\hline D3. LnP & . & D3. 1/LnP & . & D3. 1/LnP & . \\
\hline Error & 185426320 & Error & 14994 & Error & 6394 \\
\hline
\end{tabular}

Where: $\mathrm{MOE}=$ modulus of elasticity, $\mathrm{kgf} / \mathrm{cm}^{2} ; \mathrm{MOR}=$ modulus of rupture, $\mathrm{kgf} / \mathrm{cm}^{2} ; \mathrm{TPL}=$ tension on proportional limit, $\mathrm{kgf} / \mathrm{cm}^{2} ; \mathrm{VS}=$ variable source; $\mathrm{MS}=$ mean square; $\mathrm{P}=$ relative position (pith-bark direction), \%; D1 = plant spacing 2.0 x $1.0 \mathrm{~m}$; D2 = plant spacing $3.0 \times 1.0 \mathrm{~m}$; D3 = plant spacing $3.0 \times 1.5 \mathrm{~m}$; (Dummy); D“i”.LnP = interaction spacing (Dummy) with the variable LnP; $\mathrm{D}$ “i”.1/LnP = interaction spacing (Dummy) with the variable $1 / \mathrm{LnP}$; ** = significant at the $1 \%$ level of error probability; ns = not significant at the $5 \%$ level of error probability.

Using the Dummy variable, it was found that only the used regression model and the relative pith-bark position presented statistical effect, in the other hand the plant spacing showed no changes among themselves in the mechanical properties of Eucalyptus grandis wood.

The modulus of elasticity variation increased in the radial direction, as shown in Figure 2A, indicating that the mechanical strength was greater near the bark, in the sapwood region of Eucalyptus grandis wood. 
This same tendency was evidenced for the modulus of rupture, which also increased the pith for the bark (Figure 2B) indicating that the highest resistance was close to the vascular cambium region. Similarly, the other mechanical properties observed, the tension on the proportional limit increased in the radial direction according to Figure 2C.

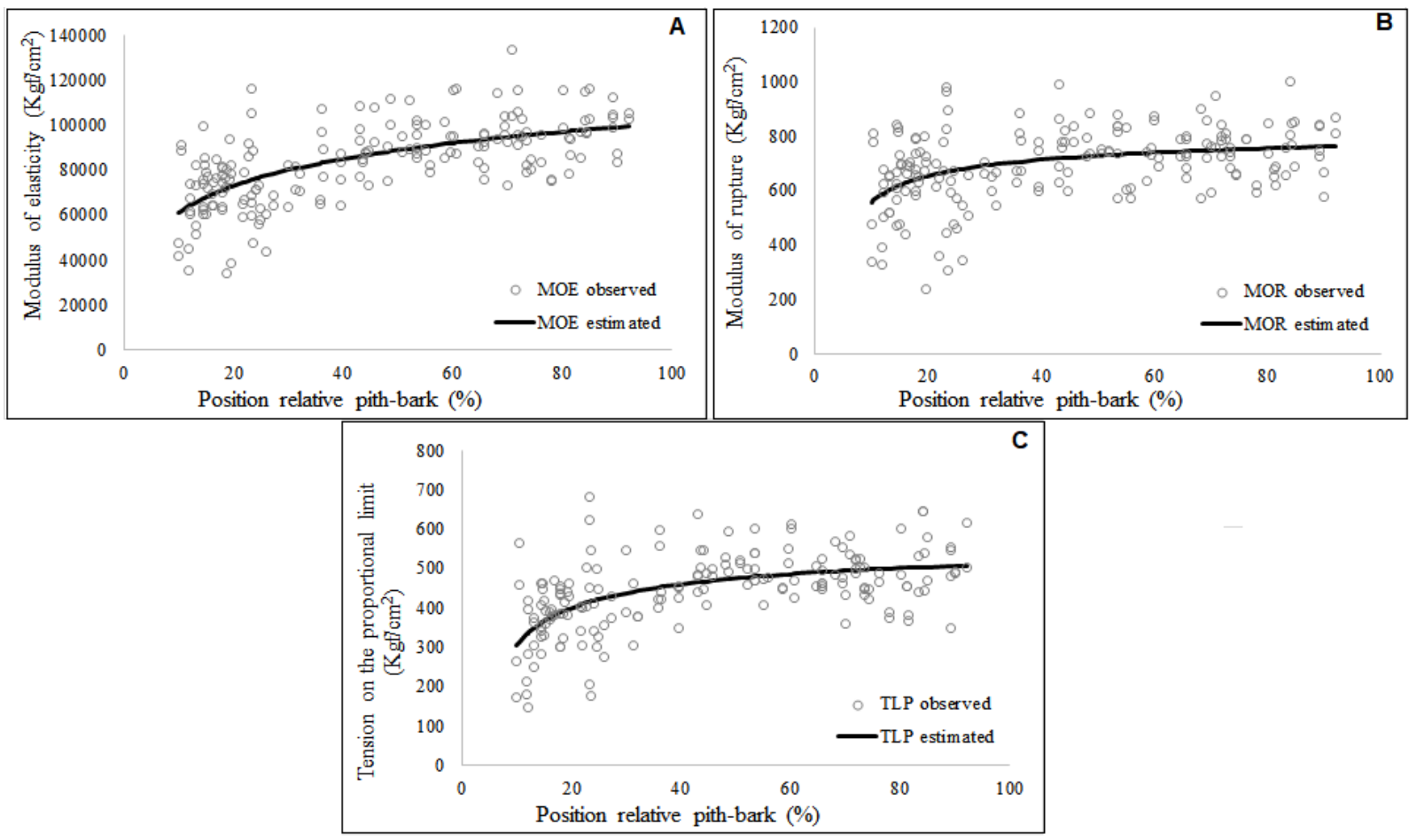

Figure 2. Mechanical properties in function of the relative position in pith-bark direction. A - Modulus of elasticity; B - Modulus of rupture; C - Tension on the proportional limit.

The means of MOR, MOE and TLP obtained for each spacing in the pith-bark position can be seen in the Table 3. The results described are in accordance with the air curves observed in the previous figures.

Table 3: Means of MOE, MOR and TLP relative position pith-bark for plant spacing.

\begin{tabular}{ccccccccccccc}
\hline \multicolumn{4}{c}{ Plant spacing 2x1 m } & \multicolumn{3}{c}{ Plant spacing 3x1 m } & \multicolumn{3}{c}{ Plant spacing 3x1,5 m } \\
\hline $\begin{array}{c}\text { Pith- } \\
\text { bark } \\
(\%)\end{array}$ & MOE & MOR & TLP & $\begin{array}{c}\text { Pith- } \\
\text { bark } \\
(\%)\end{array}$ & MOE & MOR & TLP & $\begin{array}{c}\text { Pith- } \\
\text { bark } \\
(\%)\end{array}$ & MOE & MOR & TLP \\
\hline 12,0 & 65794,5 & 598,875 & 310,37 & 12 & 73666,5 & 655,5 & 385,42 & 10 & 42409,5 & 383,225 & 206,6 \\
20,0 & 75816,56 & 654,5556 & 393,9578 & 15 & 70565,83 & 627,4 & 356,4267 & 15 & 74065,3 & 665,78 & 397,553 \\
25,0 & 67553 & 639,58 & 400,32 & 20 & 72069,56 & 661,2875 & 444,34 & 20 & 75921,1 & 687,8273 & 397,149 \\
30,0 & 70581,75 & 593,075 & 390,22 & 25 & 56247,25 & 480,575 & 351,68 & 30 & 72898 & 682,65 & 466,94 \\
37,0 & 92650 & 787,425 & 503,8575 & 30 & 76459 & 625,55 & 382,13 & 35 & 65973,5 & 651,35 & 410,46 \\
50,0 & 91582,5 & 742,75 & 517,15 & 40 & 77442,75 & 685,525 & 419,2425 & 45 & 90620,1 & 785,9833 & 501,788 \\
60,0 & 100104,8 & 751,8 & 501,4217 & 45 & 89730,5 & 744,5 & 492,9217 & 50 & 94406,2 & 784,025 & 530,86 \\
65,0 & 90610,5 & 759,6 & 486,67 & 50 & 100205,5 & 742,8 & 478,675 & 55 & 93704,6 & 763,975 & 500,087 \\
70,0 & 92611,25 & 760,75 & 472,43 & 55 & 80662 & 588,95 & 477,45 & 60 & 91426,5 & 742,65 & 530,3 \\
85,0 & 101213 & 782,925 & 509,3238 & 65 & 85762,5 & 713,175 & 465,0675 & 70 & 99343,8 & 744,25 & 475,85 \\
- & - & - & - & 70 & 103632,1 & 797,7 & 531,2429 & 75 & 84980,2 & 688,875 & 437,96 \\
- & - & - & - & 80 & 82498 & 696,9 & 429,6175 & 80 & 94775,3 & 722,3167 & 494,921 \\
- & - & - & - & 90 & 103888 & 838,75 & 560,52 & 90 & 98278,6 & 733,316 & 483,956 \\
\hline
\end{tabular}


Where: $\mathrm{MOE}=$ modulus of elasticity, $\mathrm{kgf} / \mathrm{cm}^{2} ; \mathrm{MOR}=$ modulus of rupture, $\mathrm{kgf} / \mathrm{cm}^{2} ; \mathrm{TPL}=$ tension on proportional limit, $\mathrm{kgf} / \mathrm{cm}^{2}$; Pith-bark = relation medulla-bark in the disk (\%), according diameter of tree.

\section{DISCUSSION}

From the results it was verified that the different growing spaces between the plants did not change the wood mechanical quality. The influence of the plant spacing is mainly related to the volume increment and little or no related to the technological properties of the material as discussed by [16], agreeing with the results of the present study.

The observed results corroborated those found by BENIN et al. [2] studying Eucalyptus benthamii, where the space between trees did not influence the wood static bending. However, these authors approached that this variable can modify the wood product obtained due to the fast growth resulting increase in wood juvenile portion, causing a decrease in the final material quality. Even SERENINE JUNIOR et al. [9] studying the wood of Eucalyptus grandis and Eucalyptus uruphylla addressed that besides the variables of spacing and position along the tree stem, age strongly influences the physical and mechanical properties of the wood.

However, although this statement and the growing spaces used in this study, equal to 2,3 and $4.5 \mathrm{~m}^{2}$, did not affect the property of static bending of Eucalyptus grandis wood, others researches concluded that larger plant spacing resulted in better technological properties [17] and, in the case of energy production by wood, larger plant spacing also became more attractive [18]. In general, the spacing has not shown influence on the wood mechanical properties may occur due to the fast rotation that is given to eucalyptus wood in pure stands, as occurred in the present study because it is a 7-year stand, because research has shown that in the first years the plant spacing does not change the characteristics that add quality to wood [8].

Regarding the radial position studied, there was an increasing tendency of the mechanical properties of static bending towards the bark. The same results were described by [2] for six-year-old Eucalyptus bentham$i i$ wood, which also indicated that any plant spacing can be applied up to the age of study, as it will not result in changes in the material quality.

In the physical properties case, the variation usually presents a radially well-defined tendency, where it is milder near the pith and goes through an increase in the direction of the bark. Similarly to this statement, it was observed in the mechanical properties, which showed a linear tendency in the pith-bark direction.

As occurred in the present study, the specific gravity in studies found for this species in the literature $[19,20]$, behaves increasingly in the pith-bark direction, being these results relevant because the specific gravity and the mechanical properties are directly related. The same authors approached that this wood technological properties tendency occurs due to the increase in the thickness of the cell walls and the fibers average length, which confers greater resistance to the material and change in the amount of empty spaces. However, in the study of [23] it did not observe alterations in the basic specific mass of the wood according to spacing and in the pith-bark direction for the Eucalyptus wood. Discussing that despite the physical technological properties do not present changes, the spacing influenced the growth format of the tree along the stem, and this characteristic may alter the mechanical properties in the radial direction of the tree, as was observed in this study.

The tendency observed in the pith-bark direction was described by [21], in a study with the species Tectona grandis, although not the same species as in the present study, hardwoods show similar behaviour, they verified that the fiber length and cell wall thickness increased considerably. This statement is directly linked to the mechanical properties, because these anatomical features influence the wood strength and hardness. The same authors also approached that, near the pith, the fiber diameter growth is reduced, resulting in lower static bending values, corroborating the results obtained in the current study.

\section{CONCLUSION}

It occurs a variation in the Eucalyptus grandis wood quality in the pith-bark relative position, presenting the best mechanical properties in the bark region and the worst near to the pith.

The plant spacing does not influence the modulus of elasticity, the modulus of rupture and the tension on the proportional limit of this species wood tested for static bending assay.

Additional studies on the influence of spacing and radial position on the mechanical properties of the species are recommended, especially at different ages, as this variation may occur and not be homogeneous. 


\section{BIBLIOGRAFIA}

[1] GALLIO, E., SANTINI, E.J., GATTO, D.A., et al., "Caracterização tecnológica da madeira de Eucalyptus benthamii Maiden et Cambage”, Scientia Agraria Paranaensis, Marechal Cândido Rondon, v. 15, n. 3, pp. 244-250, 2016.

[2] BENIN, C.C., WATZLAWICK, L.F., HILLIG, É., "Propriedades físicas e mecânicas da madeira de Eucalyptus benthamii sob efeito do espaçamento de plantio", Ciência Florestal, Santa Maria, v. 27, n. 4, pp. 1375-1384, 2017.

[3] LOPES, E.D., LAIA, M.L., SANTOS, A.S., et al., "Influência do espaçamento de plantio na produção energética de clones de Corimbia e Eucalyptus", Floresta, Curitiba, v. 47, n. 1, pp. 95-104, 2017.

[4] ELOY, E., CARON, B.O., SILVA, D.A., et al., "Influência do espaçamento nas características energéticas de espécies arbóreas em plantios de curta rotação", Revista Árvore, Viçosa, v. 38, pp. 551-559, 2014.

[5] FERREIRA, D.H.A.A., LELES, P.S.S., MACHADO, E.C., et al., "Crescimento de clone de Eucalytpus uruphylla x E. grandis em diferentes espaçamentos”, Floresta, Curitiba, v. 44, n. 3, pp. 431-440, 2014.

[6] TONINI, H., SCHWENGBER, D.R., MORALES, M.M., et al., "Crescimento, biomassa e qualidade energética da madeira de Acacia mangium em diferentes espaçamentos”, Pesquisa Agropecuária Brasileira, Brasília, v. 53, n. 7, p.791-799, 2018.

[7] LATORRACA, J.V.F., ALBUQUERQUE, C.E.C, "Efeito do rápido crescimento sobre as propriedades da madeira", Floresta e Ambiente, Seropédica, v. 7, n. 1, p. 279-291, 2000.

[8] LIMA, I.L., LONGUI, E.L., GARCIA, R., et al., "Propriedades da Madeira de Eucalyptus umbra R. T. Baker em função do diâmetro e da posição radial na tora", Floresta e Ambiente, Seropédica, v. 18, n. 3, pp. 289-298, 2011.

[9] SERENINE JUNIOR, L., MELO, R.R., CASTRO, V.G., et al., "Qualidade da madeira juvenil de um híbrido clonal (Eucalyptus grandis x Eucalyptus urophylla-H13)", Advances in Forestry Science, Cuiabá, v. 16, n. 1, pp. 523-527, 2019.

[10] GARCIA, C.H., CORRADINE, L., ALVARENGA, S.F., "Comportamento florestal do Eucalyptus grandis e Eucalyptus saligna em diferentes espaçamentos”, Circular técnica IPEF, Piracicaba, v. 179, 10 pp., 1991.

[11] RIOS, P.D., VIEIRA, H.C., PEREIRA, G.F., et al., "Variação radial e longitudinal da densidade básica da madeira de Pinus patula”, Pesquisa Florestal Brasileira, Colombo, v. 38, 2018.

[12] BERGER, R., SCHNEIDER, P.R., FINGER, C.A.G., et al., "Growth rate of Eucalyptus saligna Smith clone affected by spacing and fertilization”, Ciência Florestal, v. 12, pp. 75-87, 2002.

[13] CRUZ, C.R., LIMA, J.T., MUNIZ, G.I.B., "Variações dentro das árvores e entre clones das propriedades físicas e mecânicas de híbridos de Eucalyptus", Scientia Forestalis, Piracicaba, v. 64, pp. 33-47, 2003.

[14] EVANGELISTA, W.V., SILVA, J.C., LUCIA, R.M.D., et al., "Propriedades físico-mecânicas da madeira de Eucalyptus urophylla S.T. Blake no sentido radial e longitudinal", Ciência da Madeira, Pelotas, v. 01, n. 02, pp. 01-19, 2010.

[15] CANDATEN, L., RODRIGUES, E.F., TREVISAN, R., et al., "Flexão estática e massa específica aparente da madeira de Inga marginata em diferentes condições de umidade", Pesquisa Florestal Brasileira, Colombo, v. 38, pp. 1-5, 2018.

[16] SEREGHETTI, G.C., LANÇAS, K.P., SARTORI, M.S., et al., "Effect of spacing on Eucalyptus urophylla x Eucalyptus grandis growth and wood basic density in short cycle plantation”, Energia na Agricultura, v. 30, pp. 57-262, 2015.

[17] MOULIN, J.C., ARANTES, M.D.C., OLIVEIRA, J.G.L., et al., "Efeito do espaçamento, idade e irrigação no volume e densidade básica do eucalipto”, Floresta e Ambiente, Seropédica, v. 24, 2017.

[18] SOARES, T.S., GOUVEIA JUNIOR, W.V., MATIAS, R.A.M., et al., "Efeito do espaçamento na produtividade energética de um povoamento de eucalipto manejado em regime de curta rotação", Nativa, Sinop, v. 6, n. 2, pp. 165-169, 2018.

[19] SILVA, J.C., OLIVEIRA, J.T.S., FILHO, M.T., et al., "Influência da idade e da posição radial na massa específica da madeira de Eucalyptus grandis Hill ex. MAIDEN", Floresta, Curitiba, v. 34, n. 1, p. 13-22, 2004.

[20] TREVISAN, R., HASELEIN, C.R., MELO, R.R., et al., "Variação radial da massa específica básica da madeira de Eucalyptus grandis W. Hill ex Maiden.”, Floresta, Curitiba, v. 38, n. 3, 2008. 
[21] GIL, J.L.R.A., BARBOZA, F.S., CONEGLIAN, A., et al., "Características físicas e anatômicas da madeira de Tectona grandis L.f. aos 7 anos de idade", Revista de Ciências Agrárias, Pernambuco, v. 41, n. 2, pp. 529-538, 2018.

[22] AMERICAN SOCIETY FOR TESTING AND MATERIALS. ASTM D143-94. Standard methods of testing small clear specimens of timber: D 143 - 94. Philadelphia, PA, 1995.

[23] BARROS, S.S., Forma do fuste e qualidade da madeira de Eucalipto em diferentes espaçamentos $e$ níveis de desbaste, Dissertação de M.Msc., Universidade Federal do Espírito Santo, Jerônimo Monteiro, ES, Brasil, 2019.

\section{ORCID}

Luana Candaten

https://orcid.org/0000-0002-7262-8214

Henrique Weber Dalla Costa

https://orcid.org/0000-0002-2770-9453

Rômulo Trevisan

Elder Eloy

https://orcid.org/0000-0002-8535-0119

Darci Alberto Gatto

https://orcid.org/0000-0002-5912-269X

https://orcid.org/0000-0002-6805-3243 